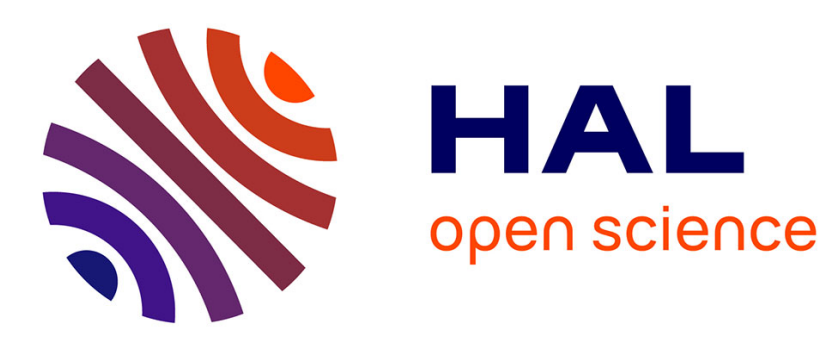

\title{
The Effects of Public Pensions on Private Wealth: Evidence on the German Savings Puzzle
}

\author{
Rainer Klump, Sangho Kim
}

\section{To cite this version:}

Rainer Klump, Sangho Kim. The Effects of Public Pensions on Private Wealth: Evidence on the German Savings Puzzle. Applied Economics, 2010, 42 (15), pp.1917-1926. 10.1080/00036840701749027. hal-00600122

\section{HAL Id: hal-00600122 \\ https://hal.science/hal-00600122}

Submitted on 14 Jun 2011

HAL is a multi-disciplinary open access archive for the deposit and dissemination of scientific research documents, whether they are published or not. The documents may come from teaching and research institutions in France or abroad, or from public or private research centers.
L'archive ouverte pluridisciplinaire HAL, est destinée au dépôt et à la diffusion de documents scientifiques de niveau recherche, publiés ou non, émanant des établissements d'enseignement et de recherche français ou étrangers, des laboratoires publics ou privés. 


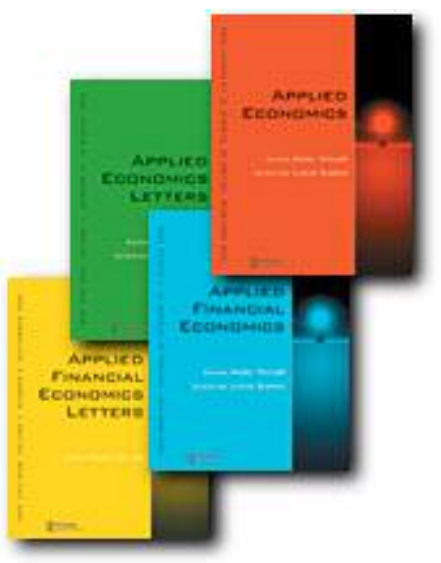

The Effects of Public Pensions on Private Wealth: Evidence on the German Savings Puzzle

\begin{tabular}{|c|c|}
\hline Journal: & Applied Economics \\
\hline Manuscript ID: & APE-07-0038 \\
\hline Journal Selection: & Applied Economics \\
\hline $\begin{array}{r}\text { Date Submitted by the } \\
\text { Author: }\end{array}$ & 19-Jan-2007 \\
\hline Complete List of Authors: & $\begin{array}{l}\text { Klump, Rainer; University of Frankfurt, Economics } \\
\text { Kim, Sangho; Kwandong University, Economics }\end{array}$ \\
\hline JEL Code: & $\begin{array}{l}\text { C23 - Models with Panel Data < C2 - Econometric Methods: Single } \\
\text { Equation Models < C - Mathematical and Quantitative Methods, D91 } \\
\text { - Intertemporal Consumer Choice|Life Cycle Models and Saving < } \\
\text { D9 - Intertemporal Choice and Growth < D - Microeconomics, H55 - } \\
\text { Social Security and Public Pensions < H5 - National Government } \\
\text { Expenditures and Related Policies < H - Public Economics, O52 - } \\
\text { Europe < O5 - Economywide Country Studies < O - Economic } \\
\text { Development, Technological Change, and Growth }\end{array}$ \\
\hline Keywords: & $\begin{array}{l}\text { Life-cycle model, Ricardian equivalence, pension systems, panel } \\
\text { estimations, Germany }\end{array}$ \\
\hline
\end{tabular}

\section{S) ScholaroNE \\ Manuscript Central}




\title{
The Effects of Public Pensions on Private Wealth: Evidence on the German Savings Puzzle
}

\author{
Sangho Kim (Kwandong University, Korea) \\ Rainer Klump (University of Frankfurt, Germany)
}

\begin{abstract}
:
Based on German panel data between 1984 and 1999 we test for the interaction of social security benefits and private wealth formation. In a simple life-cylce model benefits from public pension systems should displace equal amounts of private retirement accumulation. Our estimate for the offset effect, corrected for several possible measurement biases, is much lower, however, than expected from pure life-cycle considerations and less than comparable estimates for the US and the UK. This result thus supports other evidence on a particular German savings puzzle which might be due to market imperfections and/or bounded rational behavior.
\end{abstract}

JEL Classification: C23, D91, H55, O52,

Keywords: Life-cycle model, Ricardian equivalence, pension systems, panel estimations, Germany

Corresponding author: Rainer Klump, Department of Economics, Johann Wolfgang Goethe-University, Schumannstr. 60, 60325 Frankfurt am Main, Germany, Tel.: +49 69798 22288, Fax: +49 69798 28121, e-mail: klump@wiwi.uni-frankfurt.de 


\section{Introduction}

By providing a safe income after retirement from active work, social security systems have contributed substantially to the reduction of poverty among the elderly in developed countries. The long-term costs of these social benefits are, however, less obvious and are not yet fully understood. They arise from various effects of social security systems on labour markets and private capital formation leading to possible reductions in future growth and real wealth. While the analysis of possible labour markets effects of the existing pay-as-you-go systems of oldage social security has boomed over the last two decades, the possible capital market and real wealth effects are still less well known. We will underline in this paper the existence and significance of the latter effects. They should be taken into account, when reforms of the existing social security systems are being discussed.

The pioneering study by Feldstein (1974) sparked the debate on whether or not transfer-based social security retirement benefits influence the saving behaviour of individuals. Following Ricardian equivalence theory as put forward by Barro (1974), there is no reason to expect any substitution in household wealth formation if the retirement transfers are financed by (lump sum) social security taxes. Other studies focusing on the life-cycle model of individual decisionmaking (e.g., Feldstein and Pellechio 1979; Bernheim 1987) came to the result that public old-age security can completely offset private household saving. Empirical investigations that so far have tested the existence and the magnitude of such offset effects had to overcome serious measurement problems and provided rather mixed results.

Our study contributes to this debate by focusing on evidence from Germany 
where the public pension system has a long history going back to the end of the $19^{\text {th }}$ century, but has also experienced a series of institutional shocks due to the two world wars, deep economic crises and the division of the country. Following Gale $(1995 ; 1998)$ we try to capture several measurement biases that can veil the true interaction between social security benefits and private capital formation. Based on German panel data between 1984 and 1999, we are able to estimate household lifetime incomes and then derive a robust estimate of the private saving offset effects of social security retirement benefits. Our estimate is much lower than expected from pure life-cycle considerations (and thus closer to the predictions from Ricardian equivalence theory) and also less than comparable estimates for the US and the UK. This result is thus another proof of a particular “German savings puzzle” (Börsch-Supan et. al. 2000, Börsch-Supan 2001) which might be due to market imperfections and/or bounded rational behavior. Our study is organized as follows. In Section 2 we review the debate on the real wealth effects of old-age social security, the possible measurements biases and previous empirical findings. In Section 3 we explain our data sample. Section 4 discusses the econometric specification and the results of our empirical test while the last section draws some conclusions.

\section{Wealth effects of old-age security: Theoretical insights, measurement problems and empirical findings}

The standard life-cycle model of consumption and wealth accumulation is the most convenient benchmark for the analysis of how an individual reallocates resources in response to the availability of old-age social security or other forms of additional pension wealth. A representative household maximizes lifetime utility subject to a lifetime budget constraint, which depends on exogenous cash 
earnings, pension benefits and given interest rates. The resulting optimal consumption and saving path over the whole lifetime implies a complete offset between any kind of pension wealth and non-pension private wealth. As Browning and Crossley (2001) note this is still the baseline result if the model is taken to the data.

Gale (1995) mentions eight sources of measurement biases that can occur in empirical analyses:

1. Controlling for cash earnings instead of total compensation as the sum of cash wages and pension benefits: Comparing two individuals with equal cash earnings but with different levels of pension wealth, the parameter on pension wealth will pick up not only the substitution effect between pension wealth and non-pension wealth but also the income effect in total compensation. This can lead to an underestimation of the true offset.

2. Ignoring different life expectancy: If one compares two individuals with the same annual pension income and the same retirement age, one can expect that the one with a longer life expectancy will have higher pension wealth and also higher non-pension wealth.

3. Omitting retirement age: Generous pension benefits induce workers to retire earlier. At the same time they will accumulate more non-pension wealth for a longer retirement period.

4. Omitting age: If one compares two individuals with identical life-cycles, but with different ages, the older one will have less pension wealth and less nonpension wealth than the younger one.

5. Ignoring endogeneity of pensions with respect to saving behaviour: One can expect that individuals who tend to save a lot are also more likely to seek jobs 
with generous pension plans.

6. Using pension wealth gross-of-taxes: Measuring pension wealth gross-oftaxes instead of net-of-taxes can generate underestimation of the offset effect. 7. Using narrow measures of non-pension wealth: Smaller offsets are generally found if narrow measures of non-pension wealth are used.

8. Measuring pension wealth with error: As pension wealth is difficult to measure, estimates with measurement error will bias the offset effect toward zero.

So far most empirical evidence in favour of the offset hypothesis comes from studies based on US data. It is shown by Gale (1998) that correcting only for the first measurement bias with the help of an adjustment factor increases the measured offset by almost one half (from 0.523 to 0.77 ). Correcting for the other measurement biases increases the measured offset even further. These results seem to confirm the life-cycle model for the US.

To the best of our knowledge, evidence based on survey data for other developed countries is available only in the cases of Israel, Italy, the Netherlands, and the United Kingdom. Building on data from five subsequent Israeli Consumer Expenditure Surveys between 1968 and 1982, Lavi and Spivak (1999) find offset coefficient in Israel lying between 0 and 0.5 . Using the Italian Survey of Household Income and Wealth for the years 1989 and 1991, Jappelli (1995) finds significant displacements effects between social security wealth and private wealth in the range of 10 and 20\%. Attanasio and Brugiavini (2003), analysing the effects of the Italian pension reform of 1992, find high offset effects close to the estimates by Gale (1998) for individuals in the middle of the life-cycle where 
liqudity constraints are the least binding. Bottazzi et al. (2006) show that the offset effects in Italy are much higher for individuals who are well informed about their future pension benefits than for those who are uninformed. Based on the Dutch Socio-Economic Panel, Alessie et al. (1997) find even more than full displacement for social security retirement benefits, but no displacement for occupational pension wealth. Using the CentER Saving Survey, Euwals (2000) is able to show, however, that the impact of the Dutch public pension scheme is not well identified, while for the occupational pensions there is a negative impact only for the highest-income-decile sample. Based on data from the U.K. Family Expenditure Survey, Attanasio and Rohwedder (2003) find a negative impact of the state earnings-related pension scheme (SERPS) on private savings with relatively high substitution elasticities for the older age groups, while for the basic state pension there is no negative impact.

Only Alessie et al. (1997), Attanasio and Brugiavini (2003), Attanasio and Rohwedder (2003) as well as Bottazi et al. (2006) make adjustments that correct for the important first measurement problem mentioned by Gale (1995), i. e the bias from controlling for social security wealth and lifetime cash earnings separately. ${ }^{1}$ From these studies one gets the impression that the size of the offset effects differs fundamentally between the US and the UK on the one side, and the countries of continental Europe on the other side.

\footnotetext{
${ }^{1}$ The solution proposed by Bernheim (1987), namely controlling for pension wealth and lifetime total compensation instead of lifetime cash earnings, is not a true alternative, since it relies on the implicit assumption of a perfect offset; see Gale (1998, p. 713 f.).
} 
Evidence on the size of such offset effects in Germany is still extremely rare. In a time series analysis Kim (1992) has shown that the effect of public old-age security on aggregate private capital accumulation in Germany has been relatively low. And we could think of many reasons why market failures and/or bounded rational behavior of households has led to only small offset effects. To give just one example, it has been conjectured by Feldstein $(1995$, p. 411) that in most European countries the confidence in long-term financial promises of governments is much lower than in the US reflecting the experiences with war, political disorder and inflation over the last century. Germany has been particularly hit by all these developments so that German would consider public pension wealth much less secure than private wealth. Liqudity constraints on underdeveloped financial markets may also have prevented German households from fully substituting private savings by public pension wealth. This is why we would expect that even after controlling for possible measurement biases, the offset effects in Germany are much less pronounced than in the US or in the UK (for the SERPS) or even in other countries of continental Europe.

\section{Data}

\subsection{Sample size}

The data for our empirical study come from the German Socio-economic Panel (GSOEP). ${ }^{2}$ It is the only panel in Germany that provides at the same time information on all the necessary key variables, such as income, non-pension wealth and pension wealth. The successive GSOEP waves from 1984 through 1999 contain data for about 4,500 West German households. GSOEP provides rich socio-economic and biographical information, which are necessary for

\footnotetext{
${ }^{2}$ For more information on the GSOEP see www.diw.de/soep.
} 
measuring lifetime income and social security wealth. For the selection of our sample the following criteria were employed:

- The household head is in 1988 at the age between 40 and 59 and works as a full-time employee longer than 1,000 hours each year from 1986 through 1990. ${ }^{3}$ If the spouse earns an income, he or she has to work as an employee, too. This excludes households from our sample in which the head or the spouse is self-employed.

- The household head or the spouse was not receiving an old-age pension or a widow's pension in the mandatory German state pension system ("Gesetzliche Rentenversicherung”) from 1986 through 1990. We focus on actively working households in order to avoid problems that a different saving behaviour of the retirees might cause.

- Households with missing information relevant for calculating pension wealth, lifetime income or non-pension wealth are excluded.

Our final sample consists of 776 households with 1,304 individuals of which 746 are male and 558 are female.

\subsection{Household non-pension net wealth}

Data on household non-pension net wealth are available in the GSOEP only for 1988. They contain the market value of real estate property (including owneroccupied housing), equity in firms, and financial assets (bank accounts, building savings contracts, and stocks and bonds) less unsecured debt. The market value of real estate property and equity is coded as a categorical variable. The value of financial assets is measured by their exact value if their value is known. Otherwise

\footnotetext{
${ }^{3}$ Excluding the younger employees helps the presence of liquidity constraints to be mitigated.
} 
it is estimated by categories. We use all these information for a broad measure of household non-pension net wealth, because - as explained above - narrow measures using just financial assets could cause a significant measurement bias. So far, a systematic evaluation of the quality of the GSOEP non-pension wealth data does not exist. A comparison by Jürges (2001, p. 396) of the GSOEP wealth data with the 1988 Einkommens- und Verbrauchsstichprobe (EVS), a microcensus by the Federal Statistical Office that provides about 40,000 household data, shows, however, that the GSOEP profile follows the EVS profile rather closely.

For the interest rates until 2005 interest rates for 10 years government bonds are used and a constant interest rate of $3.5 \%$ is employed for the years thereafter. In order to check whether or not our results are sensitive to the future interest rate, an interest rate of $5.5 \%$ is employed in one of our sensitivity analyses. For the calculation of real values we make use of the German consumer price index until 2005 , and a constant value of $2 \%$ is assumed for the years after 2005 in accordance with implicit inflation target of the European Central Bank.

\subsection{Household lifetime income}

Estimating lifetime income is essential for testing the offset hypothesis. According to the life-cycle model lifetime income, and not current income, should be used for testing possible substitution in saving. Other empirical studies estimate lifetime income either based on data from only one year (e.g., Gale 1998) or several years (e.g., Jappelli 1995; Euwals 2000). Bernheim (1987) uses panel data of a longer time period, but employs a simple extrapolation for estimating yearly earnings in the future. We calculate lifetime income by estimating annual incomes based on the rich information available in the GSOEP. This econometric 
estimation method helps to reduce the possible measurement error.

Because annual income data from 1984 through 1999 were available, income development for the years excluding this period needs to be calculated for each individual. For estimates of annual income before 1984, the activity history by years of age provided by GSOEP is used, while for the calculation of annual income after 1999 it is assumed that the final information on the economic activity and on the kind of occupation also holds true in future years. Following King and Dicks-Mireaux (1982), Kazarosian (1997) and Jürges (2001), our study applies the following estimation equation for the annual income functions:

$$
\ln E_{i t}=x_{i t} \chi+v_{i}+e_{i t}
$$

In this equation $\ln E_{i t}$ is the $\log$ of net or gross annual income for individual $i$ in year $t . x_{i t}$ is a vector of time-varying observable characteristics (including a constant) for individual $i$ in year $t$, such as a fourth-order polynomial of age, a dummy variable for female household heads, the number and the squared number of children up to age 16 living in the household, and dummies for 10 kinds of occupation. $\chi$ benotes the parameter vector to be estimated. $v_{i} \sim N\left(0, \delta_{v}^{2}\right)$ is a time-invariant and unobservable individual specific effect resulting from education, gender and unobserved skills. $e_{i t}$ is an error term. A Hausman test strongly indicates that individual effects are not uncorrelated to the regressors. Therefore the fixed effects estimates can be employed in our study for calculating individual annual income. Table 1 shows the estimated determinants of individual gross annual income that can then be used for calculation of public pension wealth. 
$<$ Table $1>$

\subsection{Public pension wealth and the adjustment factor}

The calculation of household public pension wealth is higly complicated by the extreme complexity of the rules (including the many changes of old rules and the introduction of new ones) under which the German social security system operates. We assume for simplicity that all employees start drawing their public retirement benefits at the age of 66 , that they expect benefit rules to remain the same in the future, and that public pensions were not taxed in the period under consideration. In the appendix we give a more detailed description of how we calculated social security pension wealth from the GSOEP data.

As Gale (1998) has noted, an explicit adjustment factor is necessary to correct the measured values of social security wealth as long as we control for cash earnings and pensions separately. This adjustment factor $Q$ is calculated in the following way:

$Q=\left(e^{x S}-1\right) /\left(e^{x T}-1\right)$

In this formula $S$ measures the years under an old-age pension coverage and $T$ is the sum of $S$ and the expected remaining lifespan. $x=\frac{r-\delta}{\rho}-r$ is a discount factor that is composed of a long-term interest rate $r$, a rate of time preference $\delta$ and a coefficient of risk aversion $\rho$. In the case of Germany we take $\mathrm{r}=0.035$, $\delta=0.02, \rho=3$ as baseline values. The total lifespan is 72 years for male employees 
and 76 years for females according to the German Death Table in 1986/88 provided by the Federal Statistical Office. Table 2 gives an overview of values of $Q$ that were calculated for German male employees under these assumptions. The same procedure was also used to calculate adjustment factors for female employees.

$<$ Table $2>$

Table 3 reports the main sample characteristics concerning lifetime income and various wealth variables for the 776 households. Because only household heads with full-time jobs are considered in our sample, the typical household is relatively affluent. Net social security wealth is calculated by subtracting the present value of future employee contributions from gross social security wealth. Reflecting the generosity of the German state pension system, household social security wealth is considerable and an important component of lifetime resources. It is striking that household social security wealth is much bigger than household non-pension net wealth. This reflects the importance of the social security system as a significant source of old-age incomes in Germany. It also implies that a small displacement effect could reduce private household assets by a relatively large amount. It is also interesting that household non-pension net wealth is almost 10 times bigger than financial assets.

$<$ Table $3>$ 


\section{Specification and regression results}

\subsection{Specification}

Following Feldstein and Pellechio (1979), Bernheim (1987) and Gale (1998), our study employs the following specification to test for the effects of the public pension scheme on household savings in Germany:

$$
W=Z \alpha+\beta \sum_{j} P_{j} Q_{j}+\varepsilon
$$

where the index $j=1,2$ stands for household head and spouse, $\alpha$ and $\beta$ are parameters to be estimated, and $\varepsilon$ is an error term. The dependant variable $W$ is household non-pension net wealth. $Z$ is a vector of variables including household net lifetime income, the age and the squared age of the household head, an interaction term between age and income, years of education (averaged over household head and spouse), a dummy for the marital status, and the number of children. $P_{j}$ is public pension wealth of the household head or the spouse resulting from expected old-age retirement transfers. $Q_{j}$ is the offset factor that should correct for the possible estimation bias due to the use of cash earnings instead of total compensation.

It should be noted that our empirical specification takes into account most of the different sources for potential estimation biases mentioned in section 2. A broad measure of non-pension wealth - household non-pension net wealth rather than financial assets - is used as the dependent variable, and age is explicitly included in the set of explanatory variables. Heterogeneity with regard to choosing jobs 
with generous pension plans is not a serious problem in this study. Since we focus on a social security system which is mandatory for all employees, the households in our sample cannot actively influence their pension rights. Measuring pension wealth gross- or net-of-taxes should not influence the results because social security retirement transfers were tax-exempted in Germany during the relevant period. Measurement error in net social security wealth can be avoided in our estimation because public pension benefits were calculated from the estimates of annual income making use of the rich information in GSOEP and from taking into account the relevant regulations in German social security legislation. The measurement error due to the use of cash earnings is explicitly corrected by the introduction of an offset factor $Q$. In the following, we present our estimation results with and without an adjustment by the offset factor. There remain two further sources of a potential measurement bias: differences in life expectancy and omission of the effective retirement age. They cannot be taken into account directly in our specification because of a lack of exact information in the available data, but they are dealt with in our sensitivity analyses.

\subsection{Regression results}

Table 4 provides the econometric results of the least absolute deviation (LAD) regressions. Because LAD regressions reduce the effect of outliers, they are useful in analysing wealth data, which are typically highly skewed (Engen et al 1994, p.105). The estimated social security wealth coefficient without adjustment by an offset factor is negative and significantly different from zero at the $1 \%$ level. This implies that public pension wealth reduces non-pension wealth, controlling for other variables, by $16 \%$. After adjustment the offset effect, which is again significant at the $1 \%$ level, increases to $22 \%$. The difference between the two 
estimates is thus more than one third.

$<$ Table $4>$

The estimates in Table 5 show a similar pattern for robust regressions. The estimated coefficient of public pension wealth without adjustment is again negative and significantly different from zero at the $1 \%$ level. It shows an offset effect of $10 \%$ for old-age retirement transfers. Adjusting public pension wealth by the factor $Q$ again raises the estimated offset to $14 \%$, which amounts to an increase of about one third.

$<$ Table $5>$

\subsection{Sensitivity Analyses}

In order to check whether or not our results are sensitive to the future interest rate of $3.5 \%$ p.a., we recalculated the regressions on the basis of a future interest rate of $5.5 \%$ p.a. It turned out that for both $\mathrm{LAD}$ and robust regressions the main results remain unchanged. The higher interest rate increases the offset effect of social security wealth before adjustment to $23 \%$ in the LAD regression and to $14 \%$ in the robust regression, while the offset effect after adjustment increases to $30 \%$ in the LAD regression and to $19 \%$ in the robust regression, respectively.

Concerning life expectancy GSOEP does not provide any direct information. GSOEP contains just a questionnaire "Have you been suffering for at least a year or chronically from a certain illness or disability?". Using this information we 
included a dummy variable for expected life expectancy in our regressions. It turned out that this dummy is statistically insignificant and that the results concerning offset effect are not modified.

GSOEP provides a questionnaire about expected retirement age, but there are too much missing data. Only 132 household heads answered correctly while 644 did not. Therefore it cannot be tested in this study whether or not retirement age exercises a major influence on our main results. After all, we find it highly plausible - in particular under the German social security regulations - to follow Bernheim (1987, p. 297) who regards retirement age as an endogenous variable that should not be used as an explanatory variable in regressions such as ours.

\section{Conclusions}

Our results underline that reactions to social security benefits differ significantly between Germany on the one side and the US, the UK as well as other countries of continental Europe on the other side. Even after making all possible adjustments that could lead to a measurement bias, the offset effect of old-age security on private wealth formation in Germany is not higher than $22 \%$ in our base model. It is interesting to note that our panel analysis thus leads to almost the same results as the time-series analysis of wealth effects of the German pension system by Kim (1992).

The estimated figures are high enough to make the introduction and enlargement of social security benefits responsible for some part of the reduction in German aggregate capital formation, but they are certainly not an impressive proof of the life-cycle hypothesis. We would rather see our results as supportive to the 
existence of a particular "German savinggs puzzle" as it was characterized by Börsch-Supan et al.(2000, p. 11): “... pensions and health insurance are generous and likely to have large crowding out effects, yet German households accumulate so much real and financial wealth and do not appear to draw it down."

Feldstein (1995, p. 411) conjectured that given the particular historical and institutional setting of social policy in continental Europe, state provided social security could not be considered a full substitute for private wealth formation. Explanations of the Geman savings puzzle (Börsch-Supan 1992, Schnabel 1999) point out that the high growth of pension income during the mid 1950s has come as a total surprise to those generations of the war and inter-war times who were not able to change their intertemporal consumption preferences rapidly enough. Household heads in our sample have been born between 1929 and 1948. Their consumption and saving habits have thus been formed under the experience or in the close memory of extreme political and economic disorder, so that the low confidence in long-term financial promises of the government (or even their overfullfilment) should not be too surprising. However, younger generations that have grown up under the stable economic and political conditions after World War II behave differently so that the aggregate offset effect can be expected to increase. Future research will have to prove this conjecture. 


\begin{abstract}
Appendix
In this study social security wealth is calculated in the same way as in the survey report "Altersvorsorge in Deutschland 1996 (AVID 1996)" by the Verband Deutscher Rentenversicherungsträger (VDR) (1999). ${ }^{4}$ It is assumed that the insured start drawing their standard old-age pension at the age of 66 and that their further lifetime follows the pattern of the German Death Table ("Allgemeine Sterbetafel") in 1986/88 provided by the Federal Statistical Office. In accordance with AVID (1996), a widow's or a widower's pension is not calculated and a value of zero is put for the pension benefits, if their minimum contribution period of five years is not completed.
\end{abstract}

First, the monthly amount of a pension at the retirement age is estimated for each individual. The process of calculating the monthly pension in Germany is extremely complex. Thus we briefly explain how we estimated the monthly pension based on the following formula:

Monthly Pension $=G \times T \times C$

where $G$ is personal earnings points, $T$ is pension type factor and $C$ is current monthly pension value.

Income up to the contribution assessment limit for each year is divided by the average income of all insured persons and is converted into personal earnings points. These values and other credited values are summed up for all insured

\footnotetext{
${ }^{4}$ For more information on AVID 1996 see www.altervorsorge-indeutschland.de/AVID96/avid96.html.
} 
periods. Periods, which are acquired by paying insurance contributions, are contributions periods. Periods, which are spent raising children and providing military or civilian service, also count as contribution periods. One personal earnings point is given to a child-raising parent for the first year following the birth of a child. Child-raising periods from the age of two through ten can be useful for pension entitlement, if a child-raising parent is unemployed during this time. One personal earnings point also applies for the period of military or civilian service. In addition the lesser of a value corresponding $75 \%$ of a personal average earnings point before this adjustment or of a 0.75 earnings point is granted for each year to a maximum of three years spent in vocational training that was conducted by the age of 25 . The same regulation also applies for full-time education from the 18 th birthday.

Pension type factor is a factor that depends on the kinds of pension. For example, a value of one is given for the standard old-age pension. Current monthly pension value is the monthly pension that an average earner is expected to receive for one year. It is adjusted each year. For future monthly pensions, estimates in Bundesministerium für Arbeit und Sozialordnung (BMA) (2000) are employed.

Second, on the basis of the estimated monthly pension, the expected amount of annual pensions for the entire retirement period is measured. Then the present value of social security pension wealth at the retirement age is calculated using the following formula.

$$
P W_{i, t}=\sum_{k=66}^{z} \frac{A_{i, k} \cdot S P_{i, t, k}}{(1+r)^{k-66}}
$$


$P_{i, t}$ is expected value of social security pension wealth for individual $i$ in the retirement year $t . Z$ is the maximum attainable age. $A_{i, k}$ stands for the annual value of old-age pension benefits for individual $i$ at age $k$ and $S P_{i, t, k}$ for gender-specific probability in year $t$ of survival for individual $i$ until the age of $k$. $r$ is the real interest rate. Finally estimates of social security pension wealth for each employee are measured in DM values of 1988.

\section{Acknowledgements}

The authors are grateful to Richard Hauser for very valuable comments and suggestions to earlier versions of this paper. Kim's research was partly sponsored by a grant from German Academic Exchange Service (DAAD) and by the Korea Research Fund. 


\section{References}

Alessie, R. J. M., Kapteyn, A., Klijn, F. (1997), Mandatory pensions and personal savings in the Netherlands. De Economist 145, 291-324.

Attanasio, O. P., Rohwedder, S. (2003), Pension wealth and household saving:

evidence from pension reforms in the United Kingdom. American Economic Review 93, 1499-1521.

Attanasion, O. P., Brugiavini, A. ( 2003), Social security and household savings. Quarterly Journal of Economics 118, 1075-1119.

Barro, R. (1974), Are government bonds net wealth? Journal of Political Economy. Journal of Political Economy 82, 1095-1117.

Bernheim, D. (1987), The economic effects of social security: toward a reconciliation of theory and measurement. Journal of Public Economics 33, 273304.

Börsch-Supan, A. (1992), Saving and consumption patterns of the elderly: the German case. Journal of Population Economics 5, 289-303.

Börsch-Supan, A. (ed.) (2001), International Comparisons in Household Savings, New York: Academic Press

Börsch-Supan, A., Reil-Held, A., Rodepeter, R., Schnabel, R., Winter, J. (2000), The German savings puzzle, Beiträge zur angewandten Wirtschaftsforschung 594600, Institut für Volkswirtschaftslehre und Statistik, Mannheim.

Bottazzi, R., Jappelli, T., Padula, M. (2006), Retirement expectations, pension reforms, and their impact on private wealth accumulation, CFS Working Paper No. 2006/10.

Browning, M., Crossley, T. F. (2001), The life-cycle model of consumption and saving. Journal of Economic Perspectives 15, 3-22. 
Bundesministerium für Arbeit und Sozialordnung (BMA)( 2000),

Rentenversicherungsbericht 2000, Bonn.

Dicks-Mireaux, L., King, M. (984), Pension wealth and household savings: tests of robustness. Journal of Public Economics 23, 115-139.

Euwals, R.( 2000), Do mandatory pensions decrease household savings?

Evidence from the Netherlands. De Economist 148, 643-670.

Feldstein, M. S. (1974), Social security induced retirement and aggregate capital accumulation. Journal of Political Economy 82, 905-926.

Feldstein, M. S. (1995), Fiscal policies, capital formation, and capitalism. European Econonomic Review 39, 399-420.

Feldstein, M. S., Pellechio, A. (1979), Social security and household wealth accumulation: new microeconomic evidence. Review of Economics and Statistics $61,361-368$

Gale, W. G. (1995), The effects of pensions on wealth: a re-evaluation of theory and evidence. Working Paper, The Brookings Institution, Washington, D.C. Gale, W. G. (1998), The effects of pensions on household wealth: a revaluation of theory and evidence. Journal of Political Economy 106, 706-723.

Jappelli, T. (1995), Does social security reduce the accumulation of private wealth? Evidence from Italian survey data. Ricerche Economiche 49, 1-31. Jürges, H. (2001), Do Germans save to leave an estate? An examination of the bequest motive, Scandinavian Journal of Economics 103, 391-414.

Kazarosian, M. (1997), Precautionary savings: a panel study, Review of Economics and Statistics 79, 241-247.

Kim, S. (1992), Gesetzliche Rentenversicherung und Ersparnisbildung der Privaten Haushalte in der Bundesrepublik Deutschland, Zeitschrift für die gesamte Versicherungswissenschaft 47, 555-578. 
King, M.A., Dicks-Mireaux, L.-D. L. (1982), Asset holdings and the life-cycle, Economic Journal 92, 247-267.

Lavi, Y., Spivak, A. (1999), The impact of pension schemes on saving in Israel, Applied Economics 31, 761-774.

Schnabel, R. (1999), Ersparnis und Vermögen im Lebenszyklus in Westdeutschland. Habilitation Thesis, University of Mannheim, Mannheim. Verband Deutscher Rentenversicherungsträger (VDR) (1999), Altersvorsorge in Deutschland 1996, Frankfurt am Main. 
Table 1: Regression results for individual gross annual incomes

\begin{tabular}{||l|l|l|l||}
\hline Independent variables & $\begin{array}{l}\text { Coefficients } \\
\text { (t-values in } \\
\text { parentheses })\end{array}$ & $\begin{array}{l}\text { Independent } \\
\text { variables }\end{array}$ & $\begin{array}{l}\text { Coefficients } \\
\text { (t-values in } \\
\text { parentheses })\end{array}$ \\
\hline Constant & $-14.688(-6.72)$ & Occupation1 & $0.427(24.55)$ \\
\hline Age1 & $21.796(11.59)$ & Occupation2 & $0.481(32.32)$ \\
\hline Age2 & $-7.327(12.20)$ & Occupation3 & $0.527(30.79)$ \\
\hline Age3 & $1.097(13.01)$ & Occupation4 & $0.552(20.29)$ \\
\hline Age4 & $-0.061(13.93)$ & Occupation5 & $0.555(13.57)$ \\
\hline Female household head & $0.121(3.51)$ & Occupation6 & $0.552(15.87)$ \\
\hline Children1 & $-0.049(-4.56)$ & Occupation7 & $0.496(27.07)$ \\
\hline Children2 & $0.003(1.08)$ & Occupation8 & $0.561(31.04)$ \\
\hline & & Occupation9 & $0.622(27.46)$ \\
\hline & & Occupation10 & $0.692(17.54)$ \\
\hline $\mathrm{R}^{2}$ & 0.197 & & \\
\hline Number of observations & 1,304 & & \\
\hline
\end{tabular}

Table 2: Estimates of the adjustment factor $Q$ for German male employees

\begin{tabular}{||l|l|l|l|l|l||}
\hline \hline \multirow{2}{*}{$\begin{array}{l}\text { Age when pension } \\
\text { coverage began }\end{array}$} & \multicolumn{4}{l}{ Current age } \\
\cline { 2 - 6 } & 40 & 45 & 50 & 55 & 60 \\
\hline 20 & 0.571 & 0.668 & 0.751 & 0.823 & 0.885 \\
\hline 25 & 0.478 & 0.597 & 0.698 & 0.785 & 0.860 \\
\hline 30 & 0.362 & 0.506 & 0.630 & 0.737 & 0.828 \\
\hline 35 & 0.208 & 0.387 & 0.540 & 0.673 & 0.787 \\
\hline \hline
\end{tabular}


Table 3: Household lifetime income and wealth

\begin{tabular}{||l|l|l|l||}
\hline \hline \multicolumn{2}{|l|}{$\begin{array}{l}\text { Household lifetime income and wealth } \\
\text { (in DM values of 1988) }\end{array}$} & Mean & $\begin{array}{l}\text { Standard } \\
\text { deviation }\end{array}$ \\
\hline \multicolumn{2}{|l|}{ Household net lifetime income } & $1,290,586$ & 511,287 \\
\hline Household social security wealth & net & 259,794 & 133,941 \\
\cline { 2 - 5 } & gross & 320,560 & 134,718 \\
\hline Household non-pension net wealth & 146,755 & 229,313 \\
\hline Financial assets & 14,988 & 24,626 \\
\hline
\end{tabular}

Table 4: Determinants of non-pension net wealth in the LAD regression

\begin{tabular}{||l|l|l||}
\hline \multirow{2}{*}{ Independent variables } & \multicolumn{2}{|l|}{$\begin{array}{l}\text { Coefficients } \\
\text { (t-values in parentheses) }\end{array}$} \\
\cline { 2 - 3 } & Unadjusted & Adjusted \\
\hline Constant & $-13.906(-2.97)$ & $-14.771(-3.24)$ \\
\hline $\begin{array}{l}\text { Household net lifetime income } \\
\text { (in DM values of 1988) }\end{array}$ & $0.049(1.09)$ & $0.044(0.98)$ \\
\hline Age & $5.331(2.78)$ & $5.638(3.02)$ \\
\hline Age2 & $-0.542(-2.75)$ & $-0.569(-2.96)$ \\
\hline Years of education & $0.076(2.24)$ & $0.075(2.28)$ \\
\hline Age-income interaction & $0.013(3.69)$ & $0.014(3.92)$ \\
\hline Married & $0.443(2.70)$ & $0.423(2.63)$ \\
\hline Number of children & $-0.080(-1.43)$ & $-0.076(-1.38)$ \\
\hline Net social security wealth & $-0.162(-3.47)$ & $-0.218(-3.48)$ \\
\hline Pseudo $R^{2}$ & 0.071 & 0.071 \\
\hline Number of observations & 776 & 776 \\
\hline \hline
\end{tabular}

Note: Variables are measured in the following units: non-pension wealth, household lifetime income, and social security wealth divided by 100,000, age is divided by 10 and age-income interaction is divided by $10^{6}$. 
Table 5: Determinants of non-pension net wealth in the robust regression

\begin{tabular}{||l|l|l||}
\hline \multirow{2}{*}{ Independent variables } & \multicolumn{2}{l|}{$\begin{array}{l}\text { Coefficients } \\
\text { (t-values in parentheses) }\end{array}$} \\
\cline { 2 - 3 } & Unadjusted & Adjusted \\
\hline Constant & $-10.581(-2.69)$ & $-10.615(-2.70)$ \\
\hline $\begin{array}{l}\text { Household net lifetime income } \\
\text { (in DM values of 1988) }\end{array}$ & $0.036(0.95)$ & $0.027(0.71)$ \\
\hline Age & $4.117(2.56)$ & $4.116(2.56)$ \\
\hline Age2 & $-0.407(-2.45)$ & $-0.405(-2.44)$ \\
\hline Years of education & $0.054(1.89)$ & $0.053(1.88)$ \\
\hline Age-income interaction & $0.007(2.17)$ & $0.007(2.27)$ \\
\hline Married & $0.528(3.82)$ & $0.527(3.81)$ \\
\hline Number of children & $-0.089(-1.85)$ & $-0.089(-1.85)$ \\
\hline Net social security wealth & $-0.103(-2.64)$ & $-0.136(-2.53)$ \\
\hline F(8, 767) & 10.16 & 10.02 \\
\hline Number of observations & 776 & 776 \\
\hline \hline
\end{tabular}

Note: Variables are measured in the following units: non-pension wealth, household lifetime income, and social security wealth are divided by 100,000, age is divided by 10 and age-income interaction is divided by $10^{6}$. 
Table 6: Determinants of non-pension net wealth in the LAD regression based on a future interest rate of $5.5 \%$ p.a.

\begin{tabular}{||l|l|l||}
\hline \multirow{2}{*}{ Independent variables } & \multicolumn{2}{l|}{$\begin{array}{l}\text { Coefficients } \\
\text { (t-values in parentheses) }\end{array}$} \\
\cline { 2 - 4 } & Unadjusted & \multicolumn{1}{l||}{ Adjusted } \\
\hline Constant & $-14.483(-3.39)$ & $-14.867(-3.06)$ \\
\hline $\begin{array}{l}\text { Household net lifetime income } \\
\text { (in DM values of 1988) }\end{array}$ & $0.026(0.58)$ & $0.017(0.33)$ \\
\hline Age & $5.524(3.16)$ & $5.690(2.86)$ \\
\hline Age2 & $-0.558(-3.10)$ & $-0.577(-2.81)$ \\
\hline Years of education & $0.075(2.41)$ & $0.075(2.10)$ \\
\hline Age-income interaction & $0.014(4.22)$ & $0.015(3.96)$ \\
\hline Married & $0.424(2.82)$ & $0.406(2.36)$ \\
\hline Number of children & $-0.074(-1.42)$ & $-0.072(-1.23)$ \\
\hline Net social security wealth & $-0.230(-3.72)$ & $-0.296(-3.15)$ \\
\hline Pseudo $R^{2}$ & 0.071 & 0.071 \\
\hline Number of observations & 776 & 776 \\
\hline \hline
\end{tabular}

Note: Variables are measured in the following units: non-pension wealth, household lifetime income, and social security wealth are divided by 100,000, age is divided by 10 and age-income interaction is divided by $10^{6}$. 
Table 7: Determinants of non-pension net wealth in the robust regression based on a future interest rate of $5.5 \%$ p.a.

\begin{tabular}{||l|l|l||}
\hline \multirow{2}{*}{ Independent variables } & \multicolumn{2}{l||}{$\begin{array}{l}\text { Coefficients } \\
\text { (t-values in parentheses) }\end{array}$} \\
\cline { 2 - 3 } & Unadjusted & \multicolumn{1}{l||}{ Adjusted } \\
\hline Constant & $-10.641(-2.72)$ & $-10.233(-2.62)$ \\
\hline $\begin{array}{l}\text { Household net lifetime income } \\
\text { (in DM values of 1988) }\end{array}$ & $0.024(0.60)$ & $0.020(0.49)$ \\
\hline Age & $4.101(2.56)$ & $3.916(2.44)$ \\
\hline Age2 & $-0.402(-2.43)$ & $-0.381(-2.30)$ \\
\hline Years of education & $0.054(1.91)$ & $0.053(1.88)$ \\
\hline Age-income interaction & $0.007(2.21)$ & $0.007(2.26)$ \\
\hline Married & $0.520(3.77)$ & $0.519(3.77)$ \\
\hline Number of children & $-0.086(-1.80)$ & $-0.086(-1.82)$ \\
\hline Net social security wealth & $-0.141(-2.48)$ & $-0.188(-2.50)$ \\
\hline F(8, 767) & 10.01 & 9.92 \\
\hline Number of observations & 776 & 776 \\
\hline \hline
\end{tabular}

Note: Variables are measured in the following units: non-pension wealth, household lifetime income, and social security wealth are divided by 100,000 , age is divided by 10 and age-income interaction is divided by $10^{6}$. 